\title{
Studi Kasus: Aksesbilitas Petani Kopi terhadap Kredit dari Lembaga Keuangan Bank
}

\section{(A Case Study: Accessibility of Coffee Farmers towards Credit to Bank as Financial Institution)}

\author{
Sheila Ruth Sartika ${ }^{1{ }^{*}}$, Tuti Karyani ${ }^{1)}$ \\ ${ }^{1)}$ Program Studi Agribisnis Fakultas Pertanian Universitas Padjadjaran Jl. Raya Bandung- \\ Sumedang Km. 21, Jatinangor, Kabupaten Sumedang, Jawa Barat, Kode Pos 45363 \\ E-mail: sheilasartika@gmail.com
}

\begin{abstract}
The development of coffee plants in Indonesia shows a rapid growth to fulfill domestic and foreign needs. However, there are still farmers who have not been able to maximize their market potential by using post-harvest technology to increase value added caused by the low accessibility of farmers to farming capital.This research aims to identify accessibility of coffee farmers to financial institution and analyze the factors of credit accessibility towards bank as financial institution of coffee farmers at Kubangsari 2 Farmers Group. The research design used quantitative design with survey research technique. The research sampling used simple random sampling with 31 sample of farmers picked. The data analysis used logit regression method with SPSS 21as a statistical tools. The results show that the coffee farmers take credit accessibility to bank (41,94\%), non-bank (3,23\%), and non-formal financial institution $(51,61 \%)$. Besides that, there is 3,23\% respondents did not access credit. The result of logit regression shows the factors that effect to credit accessibility of coffee farmers is age, formal education, farming experience, number of coffee trees, and coffee farming income.
\end{abstract}

Keywords: credit accesibility, farming income, logit regression

DOI: http://dx.doi.org/10.25181/jaip.v6i2.954

Diterima: 2 Juli 2018 / Disetujui: 30 September 2018 / Diterbitkan: 20 Oktober 2018

\section{PENDAHULUAN}

Tanaman perkebunan merupakan komoditas pertanian potensial untuk dikembangkan di berbagai negara. Hasil perkebunan memiliki nilai yang tinggi di pasar domestik maupun pasar internasional. Salah satu tanaman perkebunan yang menjadi komoditas ekspor Indonesia adalah kopi. Kopi merupakan komoditas ekspor utama yang dikembangkan di Indonesia dengan luas lahan pengembangan kopi di Indonesia 1.227.787 ha. Produksi kopi di Indonesia pada tahun 2017 diperkirakan mencapai 637.539 ton dengan 35\% untuk memenuhi kebutuhan domestik dan 65\% untuk memenuhi kebutuhan pasar internasional (Direktorat Jenderal Perkebunan, 2016).

Jawa Barat merupakan salah satu wilayah pengembangan kopi di Indonesia. Luas lahan pengembangan kopi di Jawa Barat mencapai 33.855 ha dengan total produksi kopi di Jawa Barat mencapai 17.684 ton. Kabupaten Bandung menjadi wilayah dengan luas lahan dan produksi terbesar di Kabupaten Bandung. Desa Pulosari adalah salah satu desa yang potensial dalam 
pengembangan kopi di Kabupaten Bandung dan merupakan cikal bakal pengembangan kopi di Kecamatan Pangalengan.Luas perkebunan kopi yang dimiliki Desa Pulosari merupakan perkebunan kopi terluas di Kecamatan Pangalengan yaitu 421,1 ha dimana mencapai 35\% total luas lahan perkebunan kopi di Kecamatan Pangalengan. Kelompok Tani Hutan Kopi yang menjadi pilot project dari pengembangan kelembagaan petani kopi di Desa Pulosari adalah Kelompok Tani Hutan Kubangsari 2. Kelompok Tani Hutan Kubangsari 2 terdiri atas 44 anggota dengan luas lahan kopi yang digarap seluas 43,13 ha dengan jenis kopi arabika. Para petani merupakan penggarap lahan Perhutani dengan sistem sharing profit (bagi hasil) atas panen kopi yang dilakukan dengan persentase $15 \%$ untuk Perhutani dan $85 \%$ untuk petani penggarap.

Sistem panen kopi yang dilakukan oleh petani di Kelompok Tani Hutan Kubangsari 2 masih menggunakan sistem ijon. Pembelian kopi dalam bentuk cherry bahkan masih dalam keadaan hijau merupakan sistem panen yang sering dilakukan oleh petani. Hal tersebut dikarenakan mereka belum memiliki teknologi pengolahan pasca panen untuk mengolah kopi.

Rendahnya tingkat penggunaan teknologi pasca panen kopi yang dilakukan oleh petani disebabkan oleh kurangnya akses modal yang diperoleh petani. Hal tersebut ditunjukkan oleh hasil observasi bahwa 90\% petani yang tergabung dalam Kelompok Tani Kubangsari 2 tidak memiliki mesin pengolah biji kopi. Biaya besar untuk menyerap teknologi pasca panen membuat petani masih bertahan dengan sistem panen ijon.Padahal, penggunaan teknologi pasca panen dalam pengolahan buah kopi memiliki pengaruh yang signifikan terhadap pendapatan petani.Penjualan kopi dalam bentuk gabah (horn skin) memiliki pengaruh nilai tambah yang tinggi dibandingkan cherry (Kirana \& Karyani, 2017).

Lembaga keuangan sebagai akses kredit bagi petani berperan untuk membiayai input produksi hingga pasca panen sehingga petani dapat meningkatkan pendapatannya.Petani yang mengalami keterbatasan modal tidak mampu melakukan usahatanisecara optimal. Beberapa hasil penelitian menunjukkan bahwa ketersediaan akses lembaga keuangan memberikan kesempatan pada petani untuk mampu membeli input produksi untuk meningkatkan nilai produksi petani dan selanjutnya berdampak pada tingkat pendapatan usahatani (Rahman et al., 2014; Iski et al., 2016; Sekyi et al., 2017).

Salah satu jenis lembaga keuangan yang tersedia dan dapat diakses oleh petani kopi Kubangsari 2 adalah lembaga keuangan bank. Akses kredit dari lembaga keuangan bank biasanya diakses oleh petani dengan lahan luas dan kerjasama pasar kuat sedangkan petani dengan lahan sempit mengalami kesulitan mengakses kredit lembaga keuangan bank dikarenakan belum memiliki aset sebagai jaminan yang masih dianggap rumit (Rahayu, 2016). Padahal, lahan kopi yang luas dan jumlah petani yang memadai akan sangat terdukung dengan akses kredit dari lembaga keuangan sebagai modal usahatani.

Tujuan penelitian ini yaitu untuk mengidentifikasi akses rumah tangga petani kopi terhadap lembaga keuangan dan menganalisis faktor-faktor aksesibilitas kredit petani kopi terhadap lembaga 
keuangan bank di Kelompok Tani Hutan Kubangsari 2, Desa Pulosari, Kecamatan Pangalengan, Kabupaten Bandung.

\section{METODE PENELITIAN}

Objek penelitian yang dikaji adalah faktor-faktor yang mempengaruhi aksesibilitas petani kopi terhadap lembaga keuangan bank.Penelitian dilaksanakan di Kelompok Tani Kubangsari 2, Desa Pulosari, Kecamatan Pangalengan, Kabupaten Bandung, Provinsi Jawa Barat. Penelitian menggunakan desain kuantitatif dengan teknik penelitian survei.

Sumber data yang digunakan adalah data primer dan data sekunder. Data primer diperoleh dari responden yang ditentukan secara simple random sampling. Jumlah populasi di dalam penelitian ini adalah 44 petani. Jumlah sampel dalam penelitian ini sebanyak 31 petani responden berdasarkan perhitungan sampel menggunakan teknik slovin. Cara memperoleh data dan informasi dilakukan dengan cara wawancara langsung menggunakan panduan wawancara yang tersedia. Data sekunder diperoleh dari data yang disediakan oleh Badan Pusat Statistik, penelusuran pustaka serta laporan dari berbagai instansi terkait.

\section{Teknik Analisis Data}

\section{Pemetaan Lembaga Keuangan}

Pemetaan lembaga keuangan yang diakses oleh para petani kopi di Kelompok Tani Kubangsari 2 untuk melihat aksesibilitas petani terhadap lembaga keuangan yang tersedia baik itu lembaga keuangan bank, lembaga keuangan bukan bank, maupun lembaga keuangan non-formal.

\section{Analisis Regresi Logit}

Analisis regresi logit dilakukan untuk mengidentifikasi dan menganalisis faktor-faktor yang mempengaruhi aksesibilitas lembaga keuangan rumah tangga petani kopi di Kelompok Tani Kubangsari 2. Analisis data dilakukan dengan menggunakan metode regresi logit dan bantuan software SPSS versi 21.

Metode regresi logit merupakan suatu metode analisis regresi yang digunakan untuk menilai hubungan antara variabel dependen (response variable) dengan sekumpulan variabel independen (predictor variable). Variabel dependen (response variable) bersifat kategorik (biner) dimana hanya memiliki dua nilai kemungkinan saja, misalnya ya atau tidak. Sementara sekumpulan variabel independen (predictor variable) biasa disebut dengan kovariat (Agresti, 2007).

Penelitian ini menggunakan variabel respons kategorik yaitu adalah akses kredit dan tidak akses kredit. Variabel respon biner sebagai variabel dependen dalam penelitian ini adalah aksesibilitas kredit petani terhadap lembaga keuangan yang dinotasikan dengan Pi dan dua kategori kemungkinan yang terjadi dalam mengakses lembaga keuangan dinotasikan dengan 1 (akses kredit) dan 0 (tidak akses kredit). Variabel independen digunakan untuk mengetahui tingkat probabilitas yang terjadi terhadap variabel dependen. Variabel independen dalam penelitian ini adalah usia 
petani $\left(\mathrm{X}_{1}\right)$, tingkat pendidikan petani $\left(\mathrm{X}_{2}\right)$, pengalaman usahatani $\left(\mathrm{X}_{3}\right)$, jumlah pohon kopi $\left(\mathrm{X}_{4}\right)$ dan pendapatan usahatani kopi $\left(\mathrm{X}_{5}\right)$. Berdasarkan variabel-variabel yang telah ditentukan, maka persamaan model logit yang digunakan dalam penelitian ini yaitu sebagai berikut.

$$
\operatorname{Ln}\left(\frac{P i}{1-P i}\right)=\alpha+\beta_{1} X_{1}+\beta_{2} X_{2}+\beta_{3} X_{3}+\beta_{4} X_{4}+\beta_{5} X_{5}
$$

Keterangan:

$\mathrm{Pi}=$ Kategori akses kredit $(1=$ akses, $0=$ tidak akses $)$

$\alpha \quad=$ Konstanta (intersep)

$\beta=$ Koefisien regresi untuk variabel prediktor $(n=1,2,3,4,5)$

$\mathrm{X}_{1}=$ Usia petani (tahun)

$\mathrm{X}_{2}$ = Lama pendidikan petani (tahun)

$\mathrm{X}_{3}=$ Pengalaman usahatani (tahun)

$\mathrm{X}_{4}=$ Jumlah pohon kopi (unit)

$\mathrm{X}_{5}=$ Total pendapatan usahatani selama 1 tahun $(\mathrm{Rp})$

\section{HASIL DAN PEMBAHASAN}

\section{Karakteristik Petani}

\section{Usia Petani Kopi}

Petani responden rata-rata berada pada usia produktif sehingga dapat melakukan pekerjaannya dengan optimal walaupun petani yang berada pada usia tidak lagi produktif cukup banyak. Jumlah petani responden terbanyak pada petani akses kredit adalah berusia 50 tahun - 59 tahun dengan jumlah petani akses kredit sebanyak 5 orang $(38,46 \%)$. Sementara itu, jumlah petani responden terbanyak pada petani tidak akses kredit adalah berusia 60 tahun s.d. 69 tahun dengan jumlah petani tidak akses kredit sebanyak 9 orang atau 50\% dari total responden tidak akses kredit. Selain itu, terdapat petani responden yang berusia dibawah 30 tahun sebanyak 1 orang. Hal tersebut dikarenakan petani tersebut melanjutkan pekerjaan orangtua dengan menjadi petani kopi.

\section{Lama Pendidikan Formal Petani}

Berdasarkan data observasi lapangan, petani responden paling banyak mengenyam pendidikan terakhir hingga tingkat $\mathrm{SD} /$ sederajat sebanyak 35 orang dengan jumlah responden yang mengakses kredit sebanyak 12 orang dan responden yang tidak mengakses kredit sebanyak 23 orang. Menurut Pak Dodo (Ketua Kelompok Tani Kubangsari 2), mayoritas tingkat pendidikan terakhir petani Sekolah Dasar (SD) berdampak kepada tingkat adopsi petani terhadap teknologi dan informasi budidaya terbaru. Penyuluhan dan bentuk sosialisasi pertanian lainnya sulit untuk merubah pemikiran dan cara bekerja mereka sehari-hari sehingga perkembangan pertanian di Desa Pulosari menjadi kurang berkembang. Selain itu, regenerasi petani kopi untuk mengembangkan 
pertanian di Desa Pulosari pun sulit.Hal tersebut dikarenakan, anak para petani kopi yang disekolahkan oleh orang tuanya ke tingkat pendidikan yang lebih tinggi tidak melanjutkan ke bidang pertanian khususnya kopi, baik itu merupakan keinginan pribadi ataupun orangtua.

\section{Pengalaman Usahatani}

Pengalaman usahatani merupakan lamanya petani melakukan usahatani terutama usahatani kopi. Berdasarkan data pengalaman usahatani responden pada Tabel 13, petani responden yang paling banyak melakukan akses kredit memiliki pengalaman usahatani antara 6-10 tahun $(38,46 \%)$ sedangkan petani responden yang tidak mengakses kredit memiliki pengalaman usahatani paling banyak antara 0-5 tahun $(38,89 \%)$.

\section{Jumlah Pohon Kopi}

Jumlah pohon kopi merupakan aset produksi utama yang dimiliki oleh petani kopi sebagai sumber pendapatan. Tanaman perkebunan yang memiliki karakteristik budidaya di wilayah kehutanan menyebabkan jumlah pohon kopi yang dimiliki dengan luasan lahan yang sama dapat memiliki jumlah pohon kopi yang berbeda. Petani responden yang melakukan akses kredit dan tidak akses terbanyak memiliki jumlah pohon $<1000$ pohon dengan persentase masing-masing $46,15 \%$ dan $55,56 \%$.

\section{Pendapatan Usahatani Kopi}

Tingkat pendapatan responden yang diukur adalah pendapatan yang diperoleh petani dari usahatani kopi dalam satu tahun terakhir atau dalam satu musim panen. Tingkat pendapatan dapat dipengaruhi oleh karakteristik budidaya usahatani kopi yang dilakukan oleh responden.Berdasarkan data observasi lapangan, dapat diketahui bahwa petani responden yang melakukan akses kredit terbanyak memiliki pendapatan antara Rp6.000.000,00—Rp10.000.000,00 dengan persentase $30,77 \%$ dari total pengakses kredit. Petani responden yang tidak melakukan akses kredit terbanyak memiliki pendapatan kurang dari Rp5.000.000,00 dengan persentase $61,11 \%$ dari total responden yang tidak melakukan akses kredit.

\section{Pemetaan Lembaga Keuangan}

\section{Jenis Lembaga Keuangan Sumber Kredit Petani Kopi}

Lembaga keuangan yang dapat diakses oleh petani kopi Kubangsari 2 sebagai sumber kredit terdiri atas lembaga keuangan formal dan lembaga keuangan non-formal yang dapat dilihat pada Tabel 1. Lembaga keuangan yang dapat diakses oleh petani kopi Kubangsari 2 sebagai sumber kredit terdiri atas lembaga keuangan bank (41,94\%), lembaga keuangan bukan bank (3,23\%), serta lembaga keuangan non-formal $(51,61 \%)$. Lembaga keuangan bank yang diakses oleh responden yaitu Bank BRI (22,58\%), BPR (12,90\%), Bukopin (3,23\%), dan Bank Kencana Soreang $(3,23 \%)$. Sementara itu, lembaga keuangan bukan bank yang dapat diakses yaitu MBK 
diakses oleh 3,23\% responden. Lembaga keuangan non-formal merupakan lembaga pembiayaan yang paling banyak diakses oleh responden dimana persentase akses untuk Bandar sebesar 35,48\% sedangkan untuk akses kredit terhadap Keluarga sebesar 16,13\%. Sementara itu, terdapat 3,23\% petani responden yang tidak mengakses kredit dikarenakan tidak suka berhutang dan memilih untuk memaksimalkan produktivitas lahan pertanian yang dimiliki, baik untuk menanam kopi maupun hortikultura seperti sawi, cabai, dan tomat.

Tabel 1.Karakteristik sumber kredit responden

\begin{tabular}{|c|c|c|}
\hline Sumber kredit & Jumlah responden & Persentase (\%) \\
\hline \multicolumn{3}{|l|}{ Lembaga Keuangan Formal } \\
\hline \multicolumn{3}{|l|}{ A. Lembaga Keuangan Bank } \\
\hline BRI & 7 & 22,58 \\
\hline BPR & 4 & 12,90 \\
\hline Bukopin & 1 & 3,23 \\
\hline BKS & 1 & 3,23 \\
\hline \multicolumn{3}{|l|}{ B. Lembaga Keuangan Bukan Bank } \\
\hline MBK & 1 & 3,23 \\
\hline \multicolumn{3}{|l|}{ C. Lembaga Keuangan Non-formal } \\
\hline Bandar & 11 & 35,48 \\
\hline Keluarga & 5 & 16,13 \\
\hline Tidak suka berhutang & 1 & 3,23 \\
\hline Total Responden & 31 & $\mathbf{1 0 0 , 0 0}$ \\
\hline
\end{tabular}

\section{Karakteristik Sumber Kredit Rumah Tangga Petani Kopi}

Setiap lembaga keuangan sebagai sumber kredit bagi usahatani kopi memiliki karakteristik yang berbeda baik itu lembaga keuangan formal maupun lembaga keuangan non-formal yang ditunjukkan oleh Tabel 2 sebagai berikut. 
Tabel 2. Karakteristik sumber kredit rumah tangga petani kopi

\begin{tabular}{|c|c|c|c|c|c|}
\hline \multirow{3}{*}{ No. } & \multirow{3}{*}{$\begin{array}{c}\text { Karakteristik skim } \\
\text { kredit }\end{array}$} & \multicolumn{4}{|c|}{ Sumber kredit } \\
\hline & & \multicolumn{2}{|c|}{ Formal } & \multicolumn{2}{|c|}{ Non-formal } \\
\hline & & Bank & Bukan bank & Keluarga & Bandar \\
\hline 1 & Bentuk kredit & Uang & Uang & Uang & Uang \\
\hline 2 & Plafon (Rp 000) & $1.000-20.000$ & $1.000-3.000$ & $50-1.000$ & $500-2.000$ \\
\hline 3 & Bunga kredit & $9 \%$ & $\begin{array}{l}\text { Bagi hasil 20\% } \\
\text { flat }\end{array}$ & $\begin{array}{l}0 \% \text { (tanpa } \\
\text { bunga) }\end{array}$ & $\begin{array}{l}\mathrm{Rp} .500 / \mathrm{kg} \text { dari } \\
\text { hasil panen }\end{array}$ \\
\hline 4 & Jenis agunan & Surat berharga & - & - & Hasil Panen \\
\hline 5 & $\begin{array}{l}\text { Bentuk } \\
\text { pengembalian }\end{array}$ & Uang & Uang & Uang & $\begin{array}{l}\text { Uang dan/atau } \\
\text { Hasil Panen }\end{array}$ \\
\hline 6 & $\begin{array}{l}\text { Lama pinjaman } \\
\text { (bulan) }\end{array}$ & $6-36$ & 12 & $1-12$ & $1-12$ \\
\hline 7 & Cara pengembalian & $\begin{array}{l}\text { Bulanan atau } 4 \\
\text { bulanan }\end{array}$ & Mingguan & $\begin{array}{l}\text { Tidak } \\
\text { ditentukan }\end{array}$ & $\begin{array}{l}\text { Selama musim } \\
\text { panen }\end{array}$ \\
\hline
\end{tabular}

\section{Analisis Aksesibilitas Petani Kopi Terhadap Lembaga Keuangan Bank}

Faktor-faktor yang mempengaruhi aksesibilitas kredit petani kopi terhadap lembaga keuangan bank dianalisis menggunakan metode regresi logit. Metode tersebut digunakan untuk menganalisis tingkat pengaruh variabel dependen terhadap variabel independen penelitian.Hasil estimasi regresi logit dapat dilihat pada Tabel 3.

Berdasarkan hasil pengujian model regresi logit yang ditunjukkan oleh Tabel 3 menunjukkan bahwa model regresi logit yang digunakan telah sesuai untuk pendugaan model faktor-faktor yang mempengaruhi aksesibilitas kredit petani kopi terhadap lembaga keuangan bank.Hal tersebut ditunjukkan oleh ratio likelihood yang tinggi sebesar 12,173 (>10) yang berarti model uji yang dilakukan sangat bermanfaat.

Nilai signifikansi ratio likelihood pendugaan faktor-faktor yang mempengaruhi aksesibilitas kredit petani kopi terhadap lembaga keuangan bank dilihat dari nilai Omnibus Test of Model Coefficients sebesar 0,000 dimana nilai p-value tersebut lebih kecil dari 0,05 $(\alpha)$ sehingga tolak $\mathrm{H}_{0}$ dan terima $\mathrm{H}_{1}$. Hasil pengujian serempak tersebut menunjukkan bahwa paling sedikit ada satu variabel independen yang berpengaruh nyata terhadap peluang mengakses kredit oleh petani kopi terhadap lembaga keuangan bank. 
Tabel 3. Hasil estimasi pengujian regresi logit

\begin{tabular}{lrrr}
\hline \multicolumn{1}{c}{ Variabel } & \multicolumn{1}{c}{ Koefisien } & p-value & Odds ratio \\
\hline Konstanta & $-102,30$ & & 0,93 \\
Usia Petani & $-0,11$ & $0,035^{*}$ & 0,25 \\
Pendidikan & 3,52 & $0,050^{*}$ & 0,65 \\
Pengalaman Usahatani & 8,39 & $0,010^{*}$ & 0,99 \\
Jumlah Pohon Kopi & 60,72 & $0,014^{*}$ & 1,88 \\
Pendapatan Usahatani & 11,69 & $0,004^{*}$ & \\
\hline-2 Log Likelihood & 12,173 & & \\
Omnibus Test of Model Coefficients & 0,000 & & \\
Nagelkerke ${ }^{2}$ & 0,834 & & \\
Hosmer and Lemeshow Test & 0,999 & & \\
\hline
\end{tabular}

Keterangan: * = berpengaruh signifikan

Kemampuan variabel independen dalam menjelaskan variabel dependen dapat dilihat dari nilai Negelkerke $\mathrm{R}^{2}$. Nilai Negelkerke $\mathrm{R}^{2}$ faktor-faktor yang mempengaruhi aksesibilitas kredit petani kopi terhadap lembaga keuangan bank sebesar 0,834 menunjukkan bahwa secara bersamasama kelima faktor mampu menjelaskan pengaruh aksesibilitas kredit petani kopi terhadap lembaga keuangan bank sebesar $83,4 \%$. Sementara itu, terdapat $16,6 \%$ faktor lain diluar model yang dapat menjelaskan faktor-faktor yang mempengaruhi aksesibilitas kredit petani kopi terhadap lembaga keuangan bank. Faktor lainnya diluar model yang dapat mempengaruhi aksesibilitas petani kopi terhadap lembaga keuangan bank adalah motivasi petani untuk meningkatkan usahatani kopi serta pengetahuan petani terhadap sumber pembiayaan kredit usahatani dari lembaga keuangan bank.

Kelayakan suatu model analisis regresi logistik dapat dilihat berdasarkan nilai Hosmer and Lemeshow Test. Berdasarkan hasil Hosmer and Lemeshow Test dengan nilai signifikansi $(\alpha)$ sebesar 0,05 dapat diketahui bahwa nilai $p$-value dari uji tersebut adalah 0,999 dimana $p$-value $\leq \alpha$ atau $\mathrm{X}_{(\alpha, \mathrm{g}-2)}^{2} \leq \mathrm{X}_{\mathrm{HL}}^{2}$ yang berarti model regresi layak digunakan dalam analisis selanjutnya karena tidak ada perbedaan yang nyata antara klasifikasi yang diprediksi dengan klasifikasi yang diamati.

Nilai konstanta model sebesar -102,30. Hal tersebut berarti ketika usia petani berusia 0 tahun, tidak mengenyam pendidikan formal, tidak memiliki pengalaman usahatani kopi, tidak memiliki pohon kopi, dan tidak memiliki pendapatan usahatani kopi maka peluang petani tersebut dalam mengakses kredit dari lembaga keuangan bank sebesar -102,30. 
Berdasarkan hasil pengujian tersebut, maka didapatkan persamaan regresi faktor-faktor yang mempengaruhi aksesibilitas kredit petani kopi terhadap lembaga keuangan bank sebagai berikut.

$$
\ln \left(\frac{P i}{1-P i}\right)=-102,30-0,11 \mathrm{X}_{1}+3,52 \mathrm{X}_{2}+8,39 \mathrm{X}_{3}+60,72 \mathrm{X}_{4}+11,69 \mathrm{X}_{5}
$$

\section{Usia Petani Kopi $\left(X_{I}\right)$}

Hasil uji regresi terhadap variabel usia petani kopi $\left(\mathrm{X}_{1}\right)$ memiliki nilai koefisien bertanda negatif sebesar 0,18 dan berpengaruh signifikan pada taraf nyata 5\%. Hal tersebut berarti peningkatan usia petani kopi akan menurunkan tingkat aksesibilitas terhadap lembaga keuangan bank. Nilai odds ratio $\mathrm{X}_{1}$ sebesar 0,93 berarti usia lebih muda memiliki kesempatan mendapatkan akses kredit dari bank 0,93 kali lipat lebih besar dibandingkan petani dengan usia lebih tua.

Hasil penelitian tersebut sejalan dengan penelitian Wati (2015) yang menjelaskan bahwa petani dengan usia lebih tua cenderung bersifat tidak mengambil resiko (risk averse) sehingga keinginan mengakses kredit kecil sedangkan petani muda memiliki kecenderungan mengambil resiko (risk taker) untuk mengembangkan usahataninya.

\section{Lama Pendidikan Formal Petani $\left(X_{2}\right)$}

Hasil uji regresi terhadap variabel tingkat pendidikan formal petani $\left(\mathrm{X}_{2}\right)$ memiliki nilai koefisien bertanda positif sebesar 3,52 dan berpengaruh signifikan pada taraf nyata $5 \%$ terhadap aksesibilitas lembaga keuangan bank. Semakin tinggi tingkat pendidikan formal petani, maka semakin tinggi aksesibilitas kredit petani terhadap lembaga keuangan bank. Nilai odds ratio variabel tingkat pendidikan formal petani sebesar 0,25 yang menunjukkan bahwa petani dengan tingkat pendidikan formal lebih tinggi memiliki kesempatan mendapatkan akses kredit dari lembaga keuangan bank 0,25 kali lipat lebih besar dibandingkan dengan petani dengan tingkat pendidikan formal yang rendah.

Hasil penelitian tersebut sejalan dengan penelitian Rahman et al. (2014), yaitu petani dengan pendidikan formal yang lebih tinggi diharapkan dapat menggunakan faktor produksi dari pembiayaan kredit untuk usahatani mereka secara optimal serta mampu memanajemen resiko usahatani dengan baik.

\section{Pengalaman Usahatani Kopi $\left(X_{3}\right)$}

Hasil uji regresi terhadap variabel pengalaman usahatani $\left(\mathrm{X}_{3}\right)$ memiliki nilai koefisien positif sebesar 8,39 dan berpengaruh signifikan. Semakin lama berpengalaman usahatani maka semakin tinggi tingkat aksesibilitas petani terhadap lembaga keuangan bank.Nilai odds ratio pengalaman usahatani kopi sebesar 0,65 berarti petani dengan pengalaman usahatani lebih lama memiliki kesempatan mendapatkan akses kredit dari lembaga keuangan bank 0,65 kali lipat lebih besar dibandingkan petani dengan pengalaman usahatani kopi yang minim. 
Hasil penelitian tersebut berbeda dengan Wati (2015) yang menemukan pengalaman usahatani lebih lama justru menurunkan akses petani terhadap kredit dikarenakan mereka dianggap lebih mampu untuk mengelola usahatani dan stabil dalam hal permodalan. Sementara itu, Sebopetji \& Belete (2009) menemukan bahwa semakin berpengalaman kreditur, maka semakin tanggap dalam menangani berbagai permasalahan yang terjadi di dalam usahanya. Hal ini menunjukkan bahwa petani tersebut dianggap semakin layak dalam menerima kredit.

\section{Jumlah Pohon Kopi $\left(X_{4}\right)$}

Hasil uji regresi terhadap jumlah pohon kopi petani $\left(\mathrm{X}_{4}\right)$ memiliki nilai positif sebesar 60,72 dan berpengaruh signifikan.Semakin banyak jumlah pohon kopi garapan petani dalam usahataninya maka semakin tinggi peluang akses kredit petani terhadap lembaga keuangan bank. Nilai odds ratio yang dimiliki sebesar 0,99 berarti petani dengan jumlah pohon kopi lebih banyak memiliki kesempatan mendapatkan akses kredit dari lembaga keuangan bank 0,99 kali lipat lebih besar dibandingkan petani dengan jumlah pohon kopi yang dimiliki sedikit. Hal tersebut dikarenakan, jumlah pohon yang ditanam akan menentukan nilai produksi usahatani (Putri, 2013).

\section{Pendapatan Usahatani Kopi $\left(X_{5}\right)$}

Hasil uji regresi logit terhadap variabel pendapatan usahatani kopi $\left(\mathrm{X}_{5}\right)$ memiliki nilai koefisien bertanda positif sebesar 11,69 dan berpengaruh signifikan. Peningkatan pendapatan usahatani kopi akan meningkatkan aksesibilitas terhadap lembaga keuangan bank. Nilai odds ratio faktor jumlah pohon kopi yang dimiliki sebesar 1,88 berarti petani dengan jumlah pendapatan yang lebih tinggi memiliki kesempatan mendapatkan akses kredit dari lembaga keuangan bank 1,88 kali lipat lebih besar dibandingkan petani dengan jumlah pendapatan yang lebih rendah.Selain itu, faktor pendapatan usahatani kopi memiliki pengaruh paling besar karena memiliki nilai statistik z terbesar yaitu 2,87. Hasil penelitian tersebut sejalan dengan hasil penelitian Nurhapsari (2016) yang menjelaskan bahwa semakin tinggi pendapatan rumah tangga petani maka semakin tinggi peluang rumah tangga petani tersebut tidak terkendala kreditnya (credit worthness tinggi).

\section{KESIMPULAN DAN SARAN}

\section{Kesimpulan}

Berdasarkan penelitian yang telah dilakukan maka dapat disimpulkan bahwa lembaga keuangan yang dapat diakses oleh petani kopi Kelompok Tani Kubangsari 2 adalah lembaga keuangan bank (Bank BRI, Bank BPR, Bank Bukopin, dan Bank Kencana Soreang) sebanyak 41,94\%, lembaga keuangan bukan bank (MBK) sebanyak 3,23\%, dan lembaga keuangan nonformal (Bandar dan Keluarga) sebanyak 51,61\%. Sementara itu, terdapat 3,23\% responden tidak melakukan akses kredit dikarenakan tidak suka berhutang. Hasil analisis regresi logit menunjukkan 
bahwa faktor-faktor yang signifikan berpengaruh terhadap aksesibilitas kredit petani kopi pada lembaga keuangan bank yaitu usia petani, lama pendidikan formal petani,pengalaman usahatani, jumlah pohon kopi, dan pendapatan usahatani kopi.

\section{Saran}

Berdasarkan hasil penelitian yang telah dilakukan, maka peneliti menyarankan adanya pengingkatan jumlah pohon kopi yang dibudidayakan untuk meningkatkan pendapatan usahatani kopi sebagai langkah untuk keberlanjutan usahatani kopi dan kemandirian finansial petani dalam berusahatani kopi. Peningkatan sosialisasi dari berbagai lembaga keuangan bank mengenai skema kredit yang dapat disesuaikan dengan kondisi dan kebutuhan petani terutama jenis Kredit Usaha Rakyat (KUR) tanpa jaminan surat berharga serta sistem pembayaran kredit 4 (empat) bulan sekali.

\section{DAFTAR PUSTAKA}

Agresti, A. (2007). An Introduction to Categorical Data Analysis. New York: John Wiley \& Sons, Inc. USA.

Direktorat Jenderal Perkebunan. (2016). Statistik Perkebunan Indonesia Komoditas Kopi 20152017. Jakarta: Sekretariat Direktorat Jenderal Perkebunan.

Putri, I. C. K. (2013). Analisis Pendapatan Petani Kakao di Kabupaten Parigi-Moutong. Jurnal EMBA: Jurnal Riset Ekonomi, Manajemen, Bisnis dan Akuntansi, 1(4), 2195-2205.

Iski, N., Kusnadi, N., \& Harianto, H. (2016). Pengaruh Kredit terhadap Pendapatan Petani Kopi Arabika di Kabupaten Aceh Tengah Provinsi Aceh. Jurnal Manajemen \& Agribisnis, 13(2), 132-144.

Nurhapsari, M. S. (2016). Analisis Kendala Kredit dan Pengaruhnya terhadap Produksi Pertanian di Jawa Barat. Unpublished undergraduate thesis, Institut Pertanian Bogor, Bogor.

Rahayu, L. (2016). Aksesibilitas petani bawang merah terhadap lembaga keuangan mikro sebagai sumber pembiayaan. AGRARIS: Journal of Agribusiness and Rural Development Research, 1(1), 52-60.

Rahman, S., Hussain, A., \& Taqi, M. (2014). Impact of agricultural credit on agricultural productivity in Pakistan: An empirical analysis. International Journal of Advanced Research in Management and Social Sciences, 3(4), 125-139.

Sebopetji, T. O., \& Belete, A. (2009). An application of probit analysis to factors affecting smallscale farmers decision to take credit: A case study of the Greater Letaba Local Municipality in South Africa. African Journal of Agricultural Research, 4(8), 718-723.

Sekyi, S., Abu, B. M., \& Nkegbe, P. K. (2017). Farm credit access, credit constraint and productivity in Ghana: Empirical evidence from Northern Savannah ecological zone. Agricultural Finance Review, 77(4), 446-462.

Kirana, S. \& Karyani, T. (2017). Perbandingan analisis nilai tambah petani dan petani pengolah pada rantai pasok koperasi produsen kopi Margamulya. Jurnal AGRISEP, 16(2), 165-176. 
Wati, D. R. (2015). Akses dan Dampak Kredit Mikro terhadap Produksi dan Pendapatan Usahatani Padi Organik di Kabupaten Bogor. Unpublished master's thesis. Institut Pertanian Bogor, Bogor. 